\title{
DETERMINANTS OF THE FINANCIAL SERVICES MARKET FUNCTIONING IN THE ERA OF THE INFORMATIONAL ECONOMY DEVELOPMENT
}

\author{
Serhiy Shkarlet ${ }^{1}$, Maksym Dubyna ${ }^{2}$ \\ Chernihiv National University of Technology, Ukraine \\ Olena Zhuk ${ }^{3}$ \\ Kyiv National University of Trade and Economics, Ukraine
}

\begin{abstract}
The financial services market is an integral part of the national economy of any country. This causes the existence of the objectively available interconnection between the said systems. That is why, by the transformation of the outlined market, some changes in the functioning of the national economy and vice versa take place. The outlined processes become the most comprehensible in the process of studying of issues of the financial services market development in the environment of the active introduction of the information technology by financial companies in their work, that is, generally in the era of the information economy development. That is why, in view of the above, within the work, the purpose of the study was defined as follows: the identification and substantiation of the determinants of the financial services market transformation within the information economy. To achieve this goal, the following tasks were set and solved: to define the essence of the information technology market; to identify the nature of the information economy; to substantiate the advantages of information technologies introducing in the field of the financial services for their consumers and producers; to find out the main transformational processes in the financial services market functioning, which occur as a result of the active introduction of new information technologies in the field of financial services provision. Method. The classic methods of scientific research are used in the article, among which are the following: observation, abstraction, comparison, systematic approach, analysis, and synthesis. Results. The peculiarities of the financial services market development in Ukraine are investigated; the characteristic features of the influence of the information technologies introduction in the sphere of providing the financial services on their consumers and producers activity are analysed. The main determinants of the financial services market functioning during the era of the information economy development were also identified, which include the following: the introduction of the online platforms for the customers servicing, improving the quality of the banking settlement and cash services, change in the process of granting loans to the economic actors. The reasons for such changes and their peculiarities are substantiated. Practical implications. The obtained results form the theoretical basis for the knowledge of the financial services market transformations in the process of the active development of information technologies and allow determining the basic trends of such changes. Also, the results of the study provide an opportunity to identify further trends in the changing financial services market, models of the financial intermediaries' functioning, and use this knowledge by planning and forecasting the financial intermediaries' activities. Value/originality. The conducted research is relevant, taking into consideration the total impact of the information technology on the development of all spheres of the society, takes into account the peculiarities of the financial services market development under the pressure of such technologies. This research was carried out within the framework of the scientific work implementation of the Department of Finance, Banking, and Insurance of Chernihiv National University of Technology (No. 0115U001149) on the topic: "Financial stability of the economic systems in the crisis conditions of management".
\end{abstract}

Key words: financial service, financial institution, fintech company, phishing, information technologies.

JEL Classification: G2, G23, O32

\footnotetext{
Corresponding author:

${ }^{1}$ Chernihiv National University of Technology.

E-mail: shkarlet@ukr.net

${ }^{2}$ Department of Finance, Banking and Insurance, Chernihiv National University of Technology.

E-mail: maksim-32@ukr.net

${ }^{3}$ Department of Economics and Business Finance, Kyiv National University of Trade and Economics.

E-mail: e_zhuk@ukr.net
} 


\section{Introductions}

In the modern world, the information technologies penetrate all spheres of the society and determine the further development of many of them. The outlined technologies become the drivers of colossal changes within different social systems and transform their functioning, adapting it to the new requirements of our reality. The use of the information technology is an objective condition for further progress of a society, states, regions, individual enterprises, and every person. Information becomes not only the most important resource of progress but also an objective condition for its implementation.

The information technologies that have already filled up all spheres of human life are actively used in the functioning of economic systems of various types. In the dualistic unity of the economy and information technology, the information economy has emerged and is actively developing. For the economic structures, the outlined technologies have huge potential for their further development, increasing the efficiency of functioning and increasing the competitiveness of many markets for goods, services, and capital.

The financial services market is an objectively existing and integral part of the financial market functioning of the country and the national economy. In its essence, the outlined market is an open and complex system, which actively interacts with the external environment. This necessitates the transformation of such a market under the pressure of various factors of external influence, including the information technology. Given the fact that within the financial services market, there is a movement of the financial resources between individual entities since, within such a process, some of them transfer funds to the disposal of others, then the information technologies provide enormous opportunities for increasing the efficiency of the outlined process, increasing the level of trust between the producers and the consumers of the financial services, and accelerating the development of such a market.

The current financial services market in Ukraine is developing at a fast pace, experiencing periodic crises of a different nature. However, the financial institutions are some of the first economic entities trying to implement the information technology in their activities, as it increases both their competitiveness and the quality of the service provision to their clients. Such a process is ongoing and every year the level of transformation of the financial services market under the influence of the information technology is only increasing. The above outlines the necessity of studying the peculiarities of the information technologies influence on the financial services market, identifying the main determinants of this market transformation within the information economy.
Issues of the information economy are being studied by many scholars today, among which the following should be highlighted first of all: Antonenko B.G., Bazhal Yu., Geyets V.M., Graham T., Grynkevych S.S., Gryshchenko A.A., Gruzina I.A., Dziad O.V., Krystynevych S.A., Malyk I.P., Nikolayev Ye.B., Popadynets O.V., Sukharev O.S., Tolstiakov R.R., Chumachenko M.Ye., and others.

The issue of the financial services market functioning is found in the scientific works of such scholars: Asmadson A., Bobrov Ye.A., Vaymanov O., Vyshyvana B.M., Voytenko O.M., Esh S.M., Klessens S., Kovalenko Yu.M., Podzygun I., Santimero A., Tytova V.A., Tretiakov M.M., Herring R., Yuriy S.I., Yurchuk G.V., Yashchuk V.V., and others. Some aspects by the research of the information technology role in the development of the financial services market were studied in the works of the following researchers: Alekseyev V.I., Berko A.Yu., Opanasovych O.V., Sergeyeva O.S., Tlusta G., Trofymchuk M.I., and others. However, given the considerable scientific progress, which has already been formed within the scientific works of these scientists, it should be noted that the works devoted to the system substantiation of peculiarities of the financial services market transformation under the influence of the information technologies are not enough, taking into consideration the potential of such technologies for changes in all spheres of modern society. This substantiates the choice of the topic of the article and its relevance.

\section{Functioning of the financial services market in space of the information economy development}

To realize a thorough and substantiate research of the impact of the information technology on the financial services market transformation, from the very beginning, it is necessary to identify the essence of the main economic categories: the financial services market and the information economy. Within the article, the information economy will be considered as a type of economic system, in which information plays a key role in the development of the main spheres and industries of the national production, is an integral part of the implementation of production, distribution, exchange, and consumption processes, the further functioning of such a system is directly related to the creation and implementation of new information technologies in the activities of the economic actors. The financial services market will be understood as a set of economic relations, arising in the process of realization of the non-material form of the interaction results, which is inherent in the consumer value, between the entities in the process of satisfaction by some participants (producers) of the needs of others (consumers) on a mutually beneficial basis, the coordination of their interests at their 
own expense, account of clients or at the expense of the attracted financial resources of other entities in accordance with the current legislation in order to profit, saving the value of assets or achieving a social effect from the implementation of such interaction (Shkarlet, 2017).

It should be noted that the financial services market functioning is always connected with the need to process large volumes of information about clients, separate segments of the financial market, to analyse trends of the enterprises' operation in the real sector of the economy, the state of which always affects the level of the activity of the specified market. The introduction of the information technology has simplified the process of collecting such information and working with it, which allowed the financial institutions to take into consideration new opportunities to create additional financial products and offer them to their customers. It is in this aspect that the information technology contributes to the financial services market development, which is transformed under their influence.

The functioning of the financial services market in an era of the active development of the information economy is a dynamic process and partly chaotic. That is why it is difficult to analyse the development of such a market in the era of active implementation of the information technology. This is especially evident during the research of the interaction of such a market and the information economy system with the aim of formulating and substantiating the theoretical, methodological, and methodical provisions of this interdependent connection.

The complexity of the analysis of the dual influence between thefinancialservicesmarketand theinformation economy is that this market is a part of the national economy and the basis of its major transformations affects the change in the economic actors' activity. In turn, the information and innovation products, which are developed within the limits of separate enterprises, specially established fintech companies, which are not part of the financial services market themselves, are, however, part of the information economy, have an impact on the development of such a market. The availability of such an epistemological problem creates the necessity of introducing in the course of conducting similar studies a set of assumptions that can justify the author's approach to the consideration of the topic of the article.

In this research, the main emphasis will be placed on identifying the trends by the financial services market functioning within the system of the information economy. The process of influencing the market itself on the development of this type of economy will be considered fragmentary. Thus, more attention will be focused on the knowledge of the peculiarities of the transformation of financial intermediaries' activities in Ukraine, in the context of the active introduction of new technologies for the provision of the financial services. Accordingly, the financial services market will be investigated as a single system for which the impact of such information innovations is exogenous. Accordingly, the financial services market will be investigated as a single system, for which the impact of such information innovations is exogenous.

Consequently, considering the outlined market as a structured system, it is difficult to identify and substantiate the essence of all possible variants of the information technology impact on the development of individual components of such a market and on it in general. This is due to the complexity of such a market, in which many financial companies and their clients operate.

For example, in the first place, the financial services market is changing due to the transformation of the work of the financial intermediaries themselves. Firstly, the information technologies are introduced into the work of such institutions, which facilitates the managerial functions automation, enhances the management quality and contributes to the growth of the financial institutions efficiency. Secondly, such a market is also transformed through the demand formation by the non-financial companies (fintech institutions), which are directly involved in the development of new information products for different institutions. Batkhin Yu. observes fintech, which appeared as an alternative to classical financial institutions, has already become a phenomenon that transforms the payment market. Global research shows: $82 \%$ representatives of the world financial market are expected to be more likely to engage fintech startups in the next three to five years. According to MasterCard studies, more than $87 \%$ of the representatives of the Ukrainian banking market fully support the introduction of the innovations, and more than half of the respondents are ready to implement financial-decision-making (Bathin, 2018). According to Accenture, the fintech startups in the whole world in 2017 were able to attract $\$ 27.4$ billion with financing by $18 \%$ more than in 2016.

\section{Features of information technologies' influence on the activity of the main subjects in the financial services market}

Information technologies have an opportunity to exercise their influence not only on the financial intermediaries' activity but also on all participants in the financial services market. At the same time, such an impact can be both positive and negative. Its basic advantages include the following:

For consumers of the financial services:

- a simple and convenient way to make payments through an online platform;

- saving time due to the lack of need to visit structural subdivisions of the financial institutions; 
- no need to communicate with the bank employees, which simplifies the process of obtaining the financial services by the clients and reducing the level of the conflict situations;

- the convenience of payment implementation throughout the day;

- increasing the level of their own financial resources management through the use of their own cabinets of clients on the sites, for example, the banking institutions, which displays all information about cash flow (Privat 24, Raiffeisen online etc.);

- reducing the cost of obtaining information about their own accounts, the speed of its receipt;

- the ability to make fast payments and transfer funds from one account to another;

- obtaining an opportunity to use certain types of banking services free of charge;

For the producers of financial services:

- attracting new customers by creating and providing more competitive financial services;

- expansion of the list of the financial services that can be provided to clients;

- increasing the channels of the financial products sale for customers (using SMS, e-mail, personal cabinets, etc.);

- reducing the operating costs of the financial institutions through the transfer of the customer service to online mode, which does not require a wide network of branches and affiliates;

- application of mechanisms for processing large amounts of data allows you to create individual financial products and maximally satisfy the needs of consumers in the relevant services;

-introduction of technologies for processing large amounts of the management information, which make it timely, simplify the way of obtaining such data between different structural units of the financial institutions, which improves the quality of management;

- the ability, through the data processing, to generate statistical, analytical reports, which will be created in an automatic mode and meet the needs of the financial institution's management and the external consumers of such information;

- increase the speed of managing the managerial information online through the introduction of unified systems for the automatic control of financial institutions with the hierarchical systems of access to various types of data;

- reducing the number of errors in the process of the data processing and creating the necessary reports, which increases the quality of the information and affects the efficiency of the financial institutions' management;

- mechanisms' introduction for the business processes automation, which makes it possible to simplify operations of a financial institution, to increase the efficiency of its work by reducing the number of employees and the probability of errors;

- enhancement of cooperation between different financial units of structural units through the improvement of processes of circulation and exchange of information between them, etc.

Consequently, the impact of the information technology on the financial services market development is indeed positive in most cases and comprises an enormous potential for its further transformation and the introduction of new innovative products. However, the experience also shows that the interaction in the system "technologymarket" is not always unambiguous from the standpoint of assessing only the impact of the relevant technologies on the change of a particular economic object, sometimes changes occur within the object itself and require the use of the information technology and then the relationship is transformed into the following form: "market-technology". The outlined only emphasizes the complex correlation of information technologies and the general information economy and the financial services market. Let us consider it more thoroughly. In Fig. 1, the model of the interaction between the financial services market and the information economy is constructed (Dubyna, 2017).

\section{Determinants of the transformation of the financial services market within the framework of the information economy}

Let's consider the decisive determinants of the financial services market transformation within the information economy, which had a powerful influence on the change in this sphere of the customer service. According to our belief, the following can be attributed to them.

1. Implementation of online platforms for providing the financial services to consumers, which completely transform the process of providing the specified services. The information technologies, as already mentioned, permeate the entire sphere of the financial services. Implementation of modern technologies in the process of their provision is one of the conditions for increasing the competitiveness of financial institutions in the competitive market for financial services. Within this market, there is a struggle for reliable clients between the financial intermediaries and simplifying the settlement process, getting loans is an asset and encouraging new clients to come to these institutions.

The fact of the online platform "Privat Bank", "Privat 24" implementation can serve as a sample. The availability of its own system of the Internet customer service allowed the bank to obtain an additional channel for the services provision, a source of income generation for the bank, and the possibility of attracting new customers, who are interested in simplifying the procedures of the settlement and cash services. The introduction by the bank of special conditions for using such a platform allowed not only to increase the number of the clients, but also to increase the number of the issued credit and deposit 


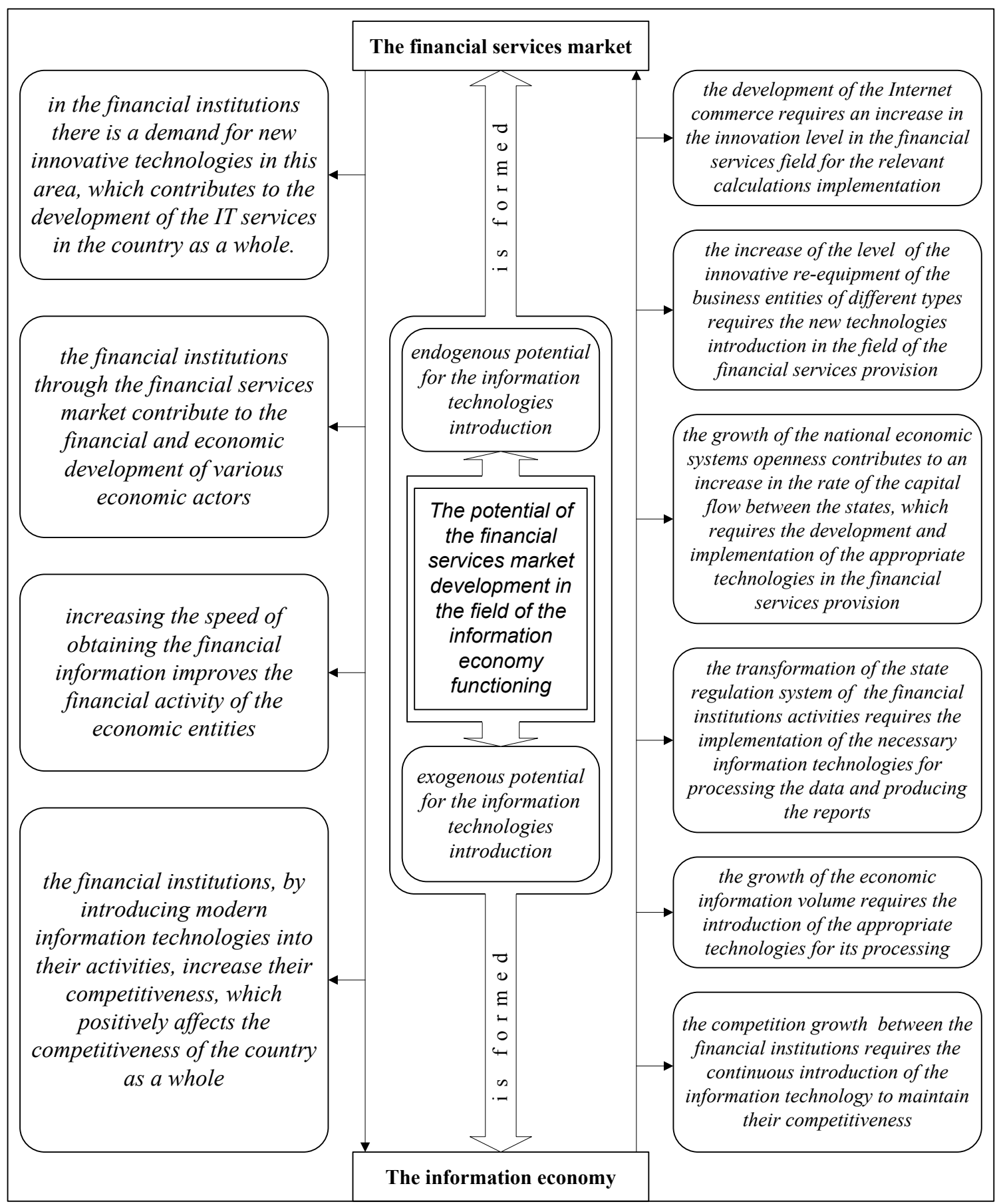

Figure 1. The interaction between the financial services market and the information economy

Source: compiled by the authors

cards, to increase the volume of the settlement and cash operations and to partially unload the cash offices in separate branches of the bank.

Online servicing is primarily associated with the ability to carry out the settlement transactions over the Internet.Inthiscase, financialinstitutions, in mostcasescommercial banks, have developed actively in recent years the models of the Internet banking, where the creation of the online systems is on the most important place. That is why, it is difficult not to argue with Yuriy G. that in the information age, the financial institutions are obliged to provide the clients with the service and the ability to manage their finances in a $24 / 7$ mode. This is not about the basic needs like money transfer or utility payment but also the ability to open a deposit, issue or repay a loan (Yuriy, 2016).

During the last two years, all system banks in Ukraine have created the online platform for providing 
the financial services to clients. This situation was objectively dictated by the time and the intensification of processes of the information technology penetration into the field of the financial services. In addition, the introduction of the abovementioned systems promotes transparency of the customer service by the banks, which is ensured by the constant ability of consumers to check their own resources, the volume of debt on the credit products, and the amounts of the accrued interest.

2. Transformation of the system of the banking settlement and the cash servicing of customers, which completely changes the process of paying by the customers for goods, works, and services. Such technologies have an impact on a wide range of consumers, who today have certain types of bankcards. The number of such clients is already large and constantly growing. The essence of the transformation is to simplify the process of paying the bills by consumers. By doing such an operation, they do not need to dial a pin code to confirm payment within a certain amount. The system itself only implements the identity of the client card. According to the Ukrainian Processing Centre, the number of payments by the contactless cards increased 3 times in 2017 and occupies 19\% of all purchases by cards at POS-terminals. The dynamic growth of these indicators, in turn, contributed to a $23 \%$ increase in the number of POS-terminals that can accept the contactless cards. Currently, $96 \%$ of all POS-terminals, connected to the Ukrainian Processing Centre and located in trading network, accept for payment the contactless cards.

Further transformation of settlement services will, in the opinion of the scientists, lead to the rapid introduction by financial institutions of mechanisms of the contactless customer service. Other financial intermediaries will be joined to the banking institutions, for which it will be easier to communicate to customers the particulars of providing them with the specific financial services and attract new customers. Gradually, the difference between a smartphone and a purse will disappear in favour of the first, which will allow the client to use a mobile phone to implement a wide range of financial services. Another service is the international transfers. The smartphone can become not only a convenient payment tool but also a personal identifier. Here we are talking not only about the calculations but also about the development of electronic administrative services: from the queues, people will gradually move on the Internet (Trofimchuk, 2012).

The introduction of technologies for the contactless customer service is associated with the transition of producers not only to financial services but also to other goods and services, to the reduction of the number of corporate cards, which provide the customers with the discounts and transfer them to the electronic form and use the smartphone hereby. It further simplifies the customer service and will result in the disappearance of the need to store a significant number of plastic cards from various financial institutions. An important aspect of increasing the convenience by using the bankcards will be their digitization, which will allow transferring all bank cards online. In particular, AlfaBank (Ukraine) became the first bank in the country, which thanks to the introduction of push provisioning technologies gave a unique opportunity to digitize their clients' cards directly into mobile banking without the need to install the Google Pay application. Now the Ukrainians do not need to carry several bank cards with them: all of them can be "settled" in the smartphone (Mironenko, 2018).

Another trend of the future in the field of the financial services will be the model of the customer identification by the biometric data, which is currently only being actively developed by the scientists for further implementation in this field. The application of such a mechanism will increase the level of security in providing the financial services and minimize the number of the abuses. According to the researchers' predictions, $29 \%$ of the smartphone owners will use fingerprint authentication in 2018. By 2023, their number will grow to more than $3 / 4$ of the smartphones' owners. $43 \%$ of smartphones will have a fingerprint reader in 2018. By 2023, the devices with biometric sensors will be twice as high. Already more fantastic, far to realization, however, perspective are processes of the use of chips in a person with the coding of all necessary information for simplifying the implementation of the everyday operations.

In the field of the settlement services, the customers actively use mobile phones, which greatly simplifies the process and increases its speed and flexibility. In particular, we'd like to note that according to the research Future Market Insights, in the world, the number of mobile payments by the results of 2016 will increase by $42 \%$ - to almost 27 million transactions. At the same time, the volume of mobile payments, according to experts, for 2016 amounted to about 768 billion dollars, against 549 billion dollars in 2015 . It is forecasted that by 2020 the volume of the mobile transactions will increase on average by $39.1 \%$, to 2.89 trillion dollars. The leading players in the global mobile payment market are PayPal, Visa, MasterCard, Google Wallet, Apple Pay, and Alipay.

3. Transforming the process of providing the credit products by various financial intermediaries, which changes the traditional mechanisms of lending to economic entities.

The credit operations have always played a key role in the development of financial intermediaries, especially those who directly lend loans to individuals and legal entities. Today, the outlined sphere, taking into consideration a significant historical process of 
its formation, transformation, and development, has become considerably more complicated by its essence: new types of loans appeared, mechanisms of their provision have changed, new financial instruments have gradually emerged, which allowed to raise funds for credit institutions and provide them for use by other entities, etc.

However, the process of granting loans is also undergoing significant changes, which allows asserting the transition of lending operations to a new stage in their development. The information technologies do not only change the mechanism of granting the loans, but affect the speed of decision-making on lending (in many cases, for example, consumer loans are issued by banks on the basis of the established algorithms that check the customer's data and give out the result at once), an opportunity to check the credit history of the clients. Such mechanisms are already beginning to be used in the process of providing services to business entities and the sale of other, first of all, consulting and operational ones. The introduction of new information technologies in the process of providing the financial services leads to a significant transformation of such a process and, in general, the business model of the financial institutions' operation. In the future, the professions of cashiers, operators, consultants will gradually disappear. Let's consider that "credit analysts, even at the current level of technology development, can replace artificial intelligence by $90 \%$. Consequently, risks of the human factor that arise when dealing with clients disappear and seriously affect the reputational capital of financial institutions" (Mironenko, 2018).

In the work of the credit institutions, special programs for calculating the cost of loans are used, calculating the entire schedule of the loans' repayment, calculating the fines and overdue payments. All this is done in automatic mode and can greatly simplify the process of issuing a loan. Quite often, the software of the financial institutions is unified with databases of the credit history bureau, which minimizes lending to fraudsters (Dubyna, 2017).

There are also obstacles to switching completely to the online loan mode for clients of financial institutions in Ukraine. In particular, in accordance with the current legislation, future borrowers must place their own signature in a loan agreement, which certifies the beginning of its operation. In order to solve this problem, the banks offer their clients to get a contract through the courier services. However, in general, such a mechanism is difficult to be implemented and it is not very convenient.

One of the trends of the credit market and total credit operations is operations such as Person-toPerson type, which actively began to develop over the past years. The essence of these operations is to combine a person who has temporarily free financial resources and is ready to provide them with a loan, and a client who needs such resources. In most cases, such a lending institution has a position of a serving company, which combines the interests of its clients through their personal interaction. This service was widely provided by PrivatBank.

According to Sophie Guibaud, Vice President for European affairs, Fidor Bank, earlier, the SEOs of the banks rarely promoted the implementation of innovations, preferring to focus on the needs of shareholders than on the needs of customers. However, in 2016 everything changed: a quarter of the financial institutions in the world were acquired by fintech companies, and $60 \%$ consider the possibility of cooperation with them (Grinkov, 2016). The credit market in Ukraine will experience a significant influence of the innovative technologies, which will increase the efficiency of its functioning and minimize the risks of both the borrowers and the creditors. The number of credit institutions in the country is constantly increasing; loan offers are also growing. However, the cost, for example, of loans, provided by credit companies is very high and unattractive to consumers. This situation requires from financial institutions to find new mechanisms for providing credit services, their transformation, and development of new types of products.

The unstable economic situation in the country, the undeveloped financial market, the persistent financial and economic crises, which are experienced by the country, and a significant devaluation of the national currency complicate the process of lending to all economic actors in the state.

It should be noted that besides the banking institutions in Ukraine, actively following the financial and economic crisis of 2008-2009, various types of credit companies began to develop. This situation was caused by a sharp rise in the financial resources deficit for the customers, which eventually contributed to the increase in the demand for the corresponding loan products. According to the research of Ukrainian E-Commerce Expert, under the results of 2016 in the market of online lending, 13 companies providing microcredit services to the population are represented exclusively through the Internet. In particular, such companies should include the following: Bystrozayem, Cash Point, CCLoan", Credit365, CreditOn, CreditUP, Eurogroshi, iKapusta, KLT Credit, MoneyBOOM, Moneyveo, MyCredit, and Ultracash. Out of them, considerable activeness in the market is demonstrated by Moneyveo, Credit365, and MoneyBOOM (Gusev, 2017).

The foregoing gives grounds for asserting, that the financial services market will be significantly affected by the introduction of new information technologies in the field of interaction between the producers and the consumers of such services. Such a process is inevitable and will only deepen in the future. However, 
despite all the benefits of the information technology to change the reality of the existing systems, they also carry threats to their functioning. Such main threats include the following:

- a significant complication of the process of the financial services providing by various institutions, which requires the introduction of new technologies, regulation of the employees' actions of such institutions, development of new mechanisms for their provision;

- the need to attract highly-skilled workers to organize the work in the field of combating the cybercrime and to build real-functioning systems to counter the thirdparty intervention in the work of financial institutions;

The amount of the cyber-shot money withdrawn from the electronic payment cards of the Ukrainians in 2016 increased to 339.13 million UAH. Often cyberattacks use such kind of fraud as "phishing" - calls to the bank customers in order to tame requisites of payment cards, necessary for conducting transactions without using a card. According to the EMA research, in 2016, the cyberattacks received from the illegal operations of "phishing" 5 times more than in 2015 - 275.45 million UAH. In addition, the loss of bankcards' users from the fraudulent transactions on the Internet in 2016 doubled - to 63.68 million UAH.

The number of phishing sites, which lurk card details from payment cardholders, in 2016 became a record number - 174 fraudulent web resources were detected and closed. Compared to 2015, the scale of phishers' actions increased more than 4.5 times (174 sites in 2016 and 38 sites in 2015). On the contrary, in 2017, the number of phishing sites began to decline - from 174 to 108 .

- in order to maintain their own competitiveness, financial institutions are obliged to create countermeasures against the fraudulent behaviour within the financial services market, which causes an objective necessity for implementing the corresponding mechanisms and technologies by such institutions and is accompanied by additional expenses;

- the need to acquire licensed software products results in an increase in the cost of implementing the online financial service delivery systems;

- the lack of full transition to the electronic document management, which is stipulated by provisions of the current legislation of Ukraine, and complicates the process of interaction with various state authorities and requires the spending of additional resources of employees of financial intermediaries;

- significant costs for providing the effective information security systems within individual financial institutions in order to prevent unauthorized penetration and their disclosure and use by other persons.

There are also other barriers to the active introduction of the information technology within the financial services market, which impede the penetration of such technologies into a particular sphere. However, the development of the information economy in the state is an inevitable process of further development of the society and will occur objectively, regardless of desires of individuals, politicians, etc. That is why the financial services market will continue to undergo strong transformations under the pressure of modern and new information and innovation products.

\section{Findings}

The article identifies determinants of the transformation of the financial services market within the information economy. A detailed analysis of advantages and disadvantages of the information technology introduction from the point of view of both producers and consumers of financial services is performed. The defining determinants that characterize the most noticeable changes in the financial services market under the pressure of new information technologies were the processes, which are actively developing today within such a market and, above all, related to the implementation of online customer service platforms, improving the quality of the banking settlement and cash services, change in the process of granting loans to the economic actors. The mentioned directions of the transformation of the financial services market are considered in detail. Also, the features of their occurrence in modern conditions of such market functioning are described.

\section{Conclusions}

The extremely important role of the information technology in the development of the financial services field is also emphasized within the article. Namely, these technologies transform all stages of providing these services to their customers. They also change the working system of financial service providers and require them to introduce new financial products. Further research in this area will only deepen the understanding of modern processes of changing the interaction system between the financial intermediaries and their clients. In particular, it is interesting to use the process approach to the very mechanism of providing the financial services, which will allow identifying and classifying already existing information technologies, used by financial institutions at certain stages of the development and implementation of such services. As well, from the scientists' point of view, issues of data systematization concerning the possibilities of information products' use in separate segments of the financial services market (credit, deposit, insurance, investment) and substantiating the essence and peculiarities of such technologies' use remain worthy further research. 


\section{References:}

339 mln UAH (2017). Biznes - Business, 4-5, 6. Retrieved from: https://www.business.ua/primarily/portret nedeli_23_29_yanvarya-360893

Batkhin Yu. (2018). Fintekh yak win-win [Fintech as win-win]. Biznes - Business, 15-16, 37. (in Ukrainian)

V Ukraini maininh stane ofitsiinym (2018). [In Ukraine, mining will become official] Biznes - Business, 10-11, 6. (in Ukrainian)

Hrynkov D., Hontar V. (2016). Karta s bytom [Map with the way of life]. Biznes - Business, 51-52 (1246-1247), 34-35. (in Ukrainian)

Gusev Iu. (2017). V stile Techno [In the Techno style.]. Biznes - Business, 6, 14-16. (in Russian)

Dubyna M.V. (2017). Osoblyvosti funktsionuvannia rynku finansovykh posluh Ukrainy u prostori rozvytku informatsiinoi ekonomiky [Special attention to the function of the financial support of Ukraine in the field of the information economy development]. Aktualni problemy formuvannia ta rozvytku informatsiinoi ekonomiky v UkrainiCurrent problems in formulating the information economy development in Ukraine. Chernihiv. P $\mathrm{p}$. 115-133. (in Ukrainian)

Kompleksne sotsiolohichne doslidzhennia Asotsiatsii «IeMA» na temu «Shakhraistvo ta hramotnist $\mathrm{u}$ sferi vykorystannia platizhnykh instrumentiv: pohliad ukrainskoho spozhyvacha» [Complex sociological research of the "IeMA" Association on the topic "Fraud and literacy in the field of the payment instruments use: a look at the Ukrainian community"] (n.d.). https://ema.com.ua. Retrieved from: https://ema.com.ua/comprehensivesociological-study-of-association-ema

Myronenko V. (2018). Minlyvyi bankinh [Changing Banking]. Biznes - Business, 15/18, 3. (in Ukrainian)

Nazvany 50 luchshikh fintekh-kompanii po versii Forbes [The 50 best fintech companies are named by Forbes]. Retrieved from: https://psm7.com/news/nazvany-50-luchshix-fintex-kompanij-po-versii-forbes.html

Osnovni tsyfry ta trendy na rynku platizhnykh kartok Ukrainy za pidsumkamy 2017 roku [The main figures and trends in the payment cards market of Ukraine in 2017]. (n.d.). https://upc.ua. Retrieved from: https://upc.ua/ua.htm

Popadynets O.V., Sheresheniuk O.M. (2016). Ekonomichni zakony informatsiinoi ekonomiky: transformatsiia tradytsiinykh postulativ ekonomichnoi teorii [Economic laws of the information economy: transformation of the traditional postulates of the economic theory]. In Accounting, analysis and audit of enterprises: problems, trends, prospects. Dublin: SAUL Publishing Ltd, pp. 135-144. (in Ukrainian)

Piatyrichka rozkvitu smartfoniv (2018). [Five Years of Prosperity of Smartphones]. Biznes - Business, 16-17, 6. (in Ukrainian)

Trofymchuk M.I. (2012). Rozvytok infokomunikatsiinoi infrastruktury finansovoho rynku [Development of the info-communication infrastructure of the financial market]. Ekonomika ta upravlinnia APK - Economics and management of the agro-industrial complex, 9, 158-160. (in Ukrainian)

Fishing v 2017 godu osvedomlennost luchshaia zashchita ot lovushek [Phishing in 2017: Awareness is the best defense against traps] (n.d.).https://ema.com.ua. Retrieved from https://ema.com.ua/phishing-statistics-results-2017

Chukhno A.I. (2008). Instytutsionalna arkhitektonika ta instytutsionalna dynamika [Institutional Architecture and Institutional Dynamics]. Ekonomika Ukrainy - Economy of Ukraine, 7, 137-143. (in Ukrainian)

Shkarlet S.M. (2014). Informatsiina ekonomika: metody, modeli ta tekhnolohiia formuvannia [The information economy: methods, models and technology of formation]. Chernihiv. (in Ukrainian)

Shkarlet S.M., Dubyna M.V. (2016). Osoblyvosti zastosuvannia kohnityvnoho pidkhodu do identyfikatsii sutnosti rynku finansovykh posluh [Features of the application of the cognitive approach to the identification of the financial services market essence]. Ekonomichnyi chasopys - Economic Journal, 3-4 (2), 70-74. (in Ukrainian)

Shkarlet S.M., Dubyna M.V. (2017). Sutnist ta osoblyvosti rozvytku informatsiinoho suspilstva [The essence and peculiarities of the information society development]. Naukovyi visnyk Polissia - Scientific bulletin of Polissia, 1 (2(10)), 152-158. (in Ukrainian)

Iur G. (2016). Bankam ne obkhodimo stanovitsia bolem tekhnologichnymi i gibkimi [Banks need to become more technologic and flexibey]. Biznes - Business, 51-52 (1246-1247), 40-41. (in Russian)

Christopher N. Sutton, Beth Jenkins (n.d.). Sutton The role of the Financial Services Sector in Expanding Economic Opportunity. Retrieved from: https://sites.hks.harvard.edu/m-rcbg/CSRI/publications/report_19_EO\%20 Finance\%20Final.pdf

Graham T.T. Molitor (2000). Trends and drivers in the information economy: strategic options for the insurance and banking industry. Foresight, 2(1), 55-68. (in English)

Martin Neil Baily, Douglas J. Elliott (n.d.). The Role of Finance in the Economy: Implications for Structural Reform of the Financial Sector. Retrieved from: https://www.brookings.edu/wp-content/uploads/2016/06/11-financerole-in-economy-baily-elliott.pdf

Noureen Adnan (n.d.). The role of the financial sector in economic growth. Retrieved from: https://www.ukdataservice.ac.uk/media/263122/noureen-paper.pdf

Shkarlet S.M., Dubyna M.V., Tarasenko A.V. (2017). Basic descriptors of the information economy development. Naukovyi visnyk Polissia - Scientific bulletin of Polissia, 1 (3(11)), 8-15. (in English) 